\title{
Assessment of Municipal Solid Waste Management in the State of Kuwait
}

\author{
A. Al Lahou and M. Alsabbagh
}

\begin{abstract}
The management of municipal solid waste (MSW) appears as a challenge for many countries in the world. The rapidly increasing amounts of waste and the consequent potential impacts necessitate proper planning and management. This paper assesses the management of the MSW in Kuwait using the driving forces-pressures-state-impacts-responses (DPSIR) framework. Applying the DPSIR method allows for understanding the causes behind the current state related to MSW along with the potential impacts and responses undertaken so far. The results of the analysis show that the generation of MSW is highly correlated with the population and economic growth in Kuwait. The per capita MSW is relatively high reaching $1.6 \mathrm{~kg} / \mathrm{capita} / \mathrm{year}$. There are several potential impacts associated with the current practices of MSWM in Kuwait. Yet, only few of them have been assessed. Kuwait has enacted the Environmental Protection Law No. 42 in 2014 where the management of the MSW is emphasized. This paper recommends the calculation of a number of waste-related performance indicators. It also recommends the conduct of a social survey for a better understanding of the consumption patterns and variations associated with the different population groups and seasons. Finally, the initiation of a regional waste-related network is highly recommended to foster collaboration and share best practices with other Gulf Cooperation Council countries.
\end{abstract}

Index Terms-DPSIR, Kuwait, municipal solid waste, performance indicators.

\section{INTRODUCTION}

The management of municipal solid waste is considered as a challenge for many countries in the world. Waste comes as a by-product along with the socio-economic development. Improper management of waste has several implications on the environmental, social, political, and economic levels. Therefore, the integrated municipal solid waste management (IMSWM) has gained importance in handling waste.

Municipal waste is defined as waste generated from household and commercial sectors. It consists of daily-use material such as packaging material, food waste, bottles, clothing, and furniture [1], [2]. It usually does not include wastewater sludge and construction waste. An extensive body of literature can be found related to the IMSWM where reducing the amount of waste comes at the top of the management hierarchy as the preferred practice and landfilling of waste at the bottom of the hierarchy as the least

Manuscript received September 10, 2018; revised December 9, 2018.

A. Al Lahou is with the Department of Natural Resources and Environment, Arabian Gulf University, P.O. Box 26671, Bahrain (e-mail: Areej_allahou@hotmail.com).

M. Alsabbagh is with the Department of Natural Resources and Environment, Arabian Gulf University, P.O. Box 26671, Bahrain (e-mail: mahamw@agu.edu.bh). preferred option. The IMSWM covers the four main stages of waste lifecycle: waste collection, transportation, processing, and disposal. Extensive literature can also be observed attempting to develop and calculate performance indicators related to the different stages of the waste lifecycle.

Yet, the IMSWM has not been fully implemented in Kuwait, a high-income country. The State of Kuwait is one of the six Gulf Cooperation Council (GCC) countries. It is located in the South Eastern part of Asia. The GCC countries in general are characterized by relatively high per capita waste generation (Fig. 1). Therefore, the GCC countries have prepared general guidelines on the prospects of implementing the IMSWM in 2013. The guidelines reviewed the status of the MSWM in each of the six GCC countries. It also made several recommendations with respect to raising the public awareness, documenting all existing waste-related legislations, ensuring the involvement of the private sector in the process, and sharing best practices between the GCC countries.

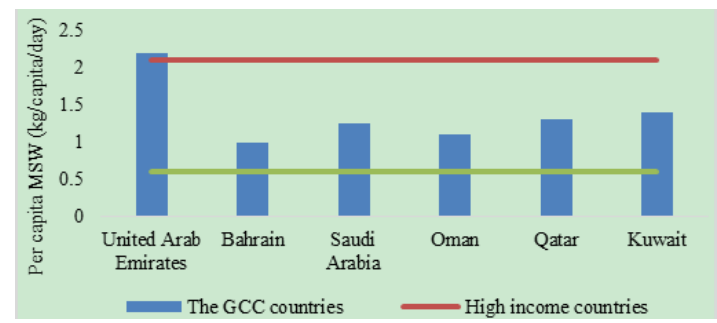

Fig. 1. Municipal solid waste in the GCC countries [3].

The literature on the municipal solid waste (MSW) in Kuwait tackles several topics including the quantification of the benefits and costs of adopting IMSWM and surveying the waste generation and composition. The earlier literature on solid waste in Kuwait attempted to develop a baseline for waste composition and to explore the correlation between waste quantity and socio-economic characteristics of the public [4]. It also investigated the public preferences towards siting landfills in Kuwait [5]. Furthermore, it assessed the MSW using the lifecycle assessment method and established an integrated databank for manufacturers and converters of plastic in Kuwait [6].

The most recent literature on the MSW in Kuwait has investigated the opportunity to implement IMSWM in Kuwait [7]. A clear trend towards the application of the lifecycle assessment method can also be observed where [8] first updated the baseline for household waste composition. Then, they used the survey results to inform the conduct of a lifecycle assessment to the MSW in Kuwait [9]. This assessment was based on the environmental impacts mainly where the meteorological conditions and geological formations were used to inform six scenarios to obtain 
realistic findings. The same results for waste composition were also used to inform the conduct of another lifecycle assessment based on the three pillars of sustainability: environment, finance, and society in [10].

Despite the existing literature on the MSW in Kuwait, literature that used performance indicators to assess its management was lacking. Such studies are of extreme importance as a first step towards a proper implementation of the IMSWM. These studies provide the baseline required to assess the effectiveness of waste-relevant practices and monitor progress towards the achievement of set targets. Accordingly, this paper aims to assess the MSWM in Kuwait through provision of historical trends of waste-relevant indicators. The following section presents the method used to achieve the aim of this paper. The third and fourth sections present the main results and discussion along with the conclusion.

\section{Methods}

There are several assessment methods that can be performed to analyze the waste issue, such as the life cycle assessment, cost-benefit, multi-criteria decision-making, risk assessment, and benchmarking [11]; the lifecycle assessment is mostly-used, though.

TABLE I: THE PERFORMANCE INDICATORS SELECTED FOR THE DPSIR FRAMEWORK FOR THE MSW IN KUWAIT

\begin{tabular}{|c|c|c|c|c|}
\hline Indicators & DP & $\mathrm{S}$ & $\mathrm{I}$ & $\mathrm{R}$ \\
\hline Economic & $\begin{array}{l}\text { - Economic growth } \\
\text { (\% of GDP growth } \\
\text { rate/year) }\end{array}$ & & $\begin{array}{l}\text { - Average operation cost per } \\
\text { metric ton (\$/ton) } \\
\text { - Expenditure on waste } \\
\text { management (\$/year) } \\
\text { - Value of waste recycled } \\
(\$ / \text { ton })\end{array}$ & $\begin{array}{l}\text { - Landfill gate fees (cost of } \\
\text { landfill disposal) } \\
\text { - Indirect economic } \\
\text { instruments to incentivize other } \\
\text { options }\end{array}$ \\
\hline Environmental & & & $\begin{array}{l}\text { - Tone of emissions } \\
\text { generated from waste } \\
\text { management in a period of } \\
\text { time }(\mathrm{t} / \text { year) } \\
\text { - } \mathrm{CO}_{2} \mathrm{e} \text { emissions generated } \\
\left(\mathrm{kg} \mathrm{CO}_{2} \mathrm{e}\right) \\
\text { - Energy consumption for } \\
\text { waste management per ton } \\
\text { (joule/t). }\end{array}$ & - Energy recovery from waste \\
\hline Social & $\begin{array}{l}\text { - Population } \\
\text { growth (\% of } \\
\text { population growth } \\
\text { rate/year) } \\
\text { - Urbanization } \\
\text { (\%/year) } \\
\text { - Households } \\
\text { growth (\%/year) }\end{array}$ & $\begin{array}{l}\text { - Total waste generated (ton/year) } \\
\text { - Per capita waste per year } \\
\text { (ton/capita/year) } \\
\text { - Waste by income group (\% of waste } \\
\text { generated/income group) } \\
\text { - } \% \text { of households that separate waste } \\
\text { - } \% \text { of people willing to separate their } \\
\text { waste } \\
\text { - \% of people that know about solid waste } \\
\text { management programs }\end{array}$ & $\begin{array}{l}\text { - } \% \text { of people not satisfied } \\
\text { with the waste management } \\
\text { system }\end{array}$ & $\begin{array}{l}\text { - Awareness / education } \\
\text { programs }\end{array}$ \\
\hline Other & & $\begin{array}{l}\text { - Total waste per sector (ton/sector/year) } \\
\text { - \% of waste collected to waste generated } \\
\text { - Recycling rate (\%/year) } \\
\text { - Amount of waste sent to landfill or } \\
\text { incinerator (ton/destination/year) } \\
\text { - Waste diversion rate (e.g., energy } \\
\text { recovery, composting of organic waste, } \\
\text { recycling, waste landfilled } \\
\text { (\%/destination/year) } \\
\text { - Waste characterization (e.g., \% of food } \\
\text { waste/year) }\end{array}$ & $\begin{array}{l}\text { - Landfill lifespan } \\
\text { - Waste collection capacity }\end{array}$ & $\begin{array}{l}\text { - Waste statistics database } \\
\text { - Making recycling legally } \\
\text { mandatory } \\
\text { - Setting targets for reducing } \\
\text { waste generation from } \\
\text { household and commercial } \\
\text { activities }\end{array}$ \\
\hline
\end{tabular}

Compiled from [13], [15]-[18]

The focus of these methods can either be on a single dimension such as the environment, economy, or society, or a combination of these dimensions. However, to initiate an IMSWM, a baseline assessment needs to be carried out to portray the current state, understand how the MSW has been developed over time, and identify its causes and impacts and how these were responded to.

Although the above-mentioned methods are widely used in literature, another method may appear more suitable for the case of Kuwait, i.e., the driving forces-pressures-state-impacts-responses (DPSIR) framework (Fig. 2 ). The DPSIR framework is an assessment method that is used for environmental-related issues in the essence but can also be used for other issues as well. It was developed by the European Environment Agency where it tracks the causes of an issue through investigating the direct and indirect causes, i.e., driving forces and pressures, illustrates its current state, documents the different impacts resulting from the issue, and finally lists down the policies and actions undertaken in response to the selected issue.

The DPSIR relies mainly on the use of indicators which are widely used in the MSW literature. The use of indicators allows for benchmarking with best practices, facilitates monitoring of progress towards achieving set targets, shows the historical development of waste-related practices, and most importantly, helps assessing the effectiveness of implementing policies related to waste minimization, recycling, and disposal. 


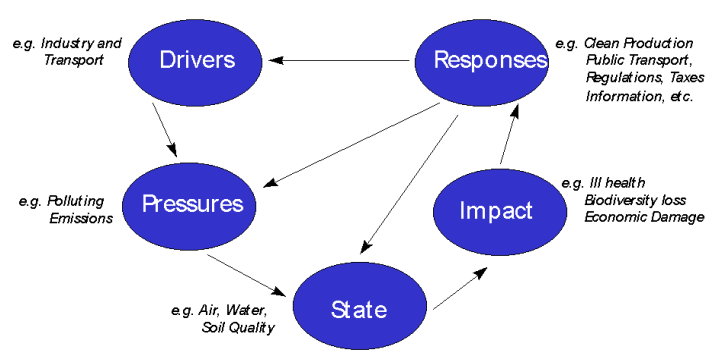

Fig. 2. The DPSIR framework [12].

In this paper, a list of waste-related performance indicators was compiled from relevant literature (Table I). Indicators are usually grouped in literature based on the stages of handling waste (e.g., waste collection, transport, and disposal), or assessment criteria (e.g., operation cost, social perception, and communication [13]. Another categorization system for indicators is based on the unit used in the calculation. In [14], the waste-related performance indicators were categorized into four tiers for which the first tier was based on absolute weight (in tons). The second and third tiers were calculated in relation to percentages and per capita rates, whereas the fourth tier was based on the lifecycle assessment including energy saving and greenhouse gas emission reductions.

The indicators used in the DPSIR framework in this paper are grouped based on the three pillars of sustainability: economy, environment, and society (Table I). Data required to calculate the indicators were obtained from several sources including the World Bank, Kuwait's Central Statistical Bureau, Kuwait Municipality, and the national communication on climate change. The data were collected for the period 1994-2016 where available; however, data for the last decade were more detailed.

\section{RESUlTS AND DISCUSSION}

\section{A. Drivers and Pressures}

Implementing the DPSIR framework for the assessment of the MSW in Kuwait revealed that as the population number in Kuwait increases, the MSW increases as well (Fig. 3). A similar correlation can clearly be observed with regard to the gross domestic product (GDP) (Fig. 4). The population number of Kuwait has increased by $5.4 \%$ annually in average during 1994-2016. The number of households (both nationals and expats) has been increasing as well with an average growth rate of $7.4 \%$ annually. Kuwait is considered as an urbanized country for which more than $98 \%$ of its population is considered urban. This percentage has remained almost unchanged during the last three decades. The economy of Kuwait has been growing at an average annual rate of $2.6 \%$ [19].

Both of the population size and the economic growth are strongly correlated with the MSW in Kuwait $\left(\mathrm{R}^{2}=0.87\right.$ and 0.81 respectively). This finding conforms to earlier literature where the population and economic growth were identified as main drivers for the increase of the MSW in Kuwait and other Arab countries [20]. This is the case because as the economy grows, the consumption patterns and lifestyle of the population change, which result in more consumption of goods due to their affordability. Additionally, people tend to purchase new items instead of recycling or repairing the ones they already have, which results in more waste.

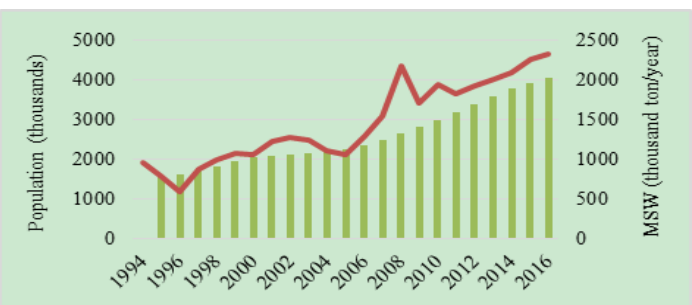

Fig. 3. The population and MSW in Kuwait during 1994-2016 [19], [21].

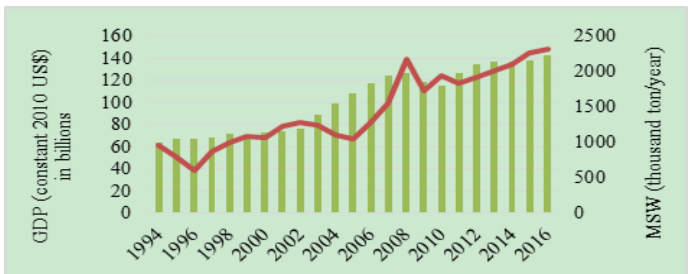

Fig. 4. The GDP and MSW in Kuwait during 1994-2016 [19], [21].

\section{B. State}

The MSW in Kuwait makes up a relatively small fraction of the total waste. The share of MSW ranged between $12 \%$ and 24\% during the period of 2005-2016 (Fig. 5). The construction waste makes the majority of the total waste in Kuwait. This is due to the urbanization and economic development in the country that necessitate the construction of new buildings and consequently generate more construction waste.

The MSW generated in Kuwait amounted to 965 thousand tons in 1994, and it increased to 2.3 million tons in 2016 with an average annual rate of $5.4 \%$ (Fig. 7). However, the per capita MSW has been fluctuating over the same period amounting to $1.6 \mathrm{~kg} /$ capita in 2016. The per capita MSW has been decreasing since 2009 due to the global financial and economic crisis that occurred in the same year. The household waste makes around $68 \%$ of the total MSW in Kuwait, and this share has decreased from 93\% in 1994 (Fig. 7).

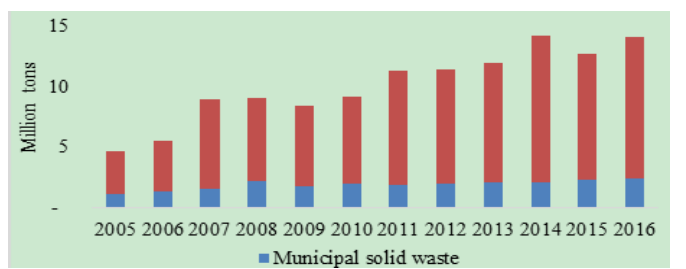

Fig. 5. Total waste in Kuwait by type between 1994 and 2016 [21]

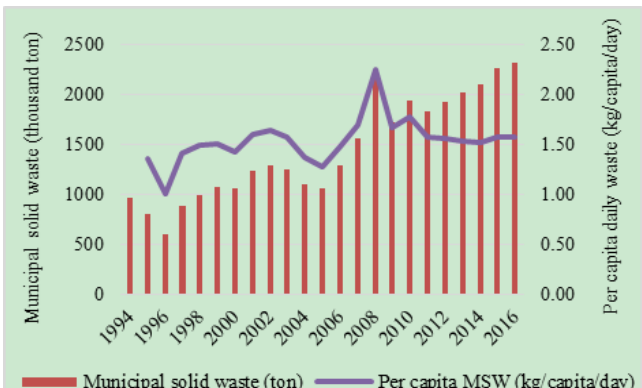

Fig. 6. Total MSW and per capita MSW in Kuwait between 1994 and 2016 (Bureau, 2018). 
There are fifteen landfills in Kuwait, of which three landfills are currently open: Mina Abdulla (Fig. 7), Al Jahra, and South $7^{\text {th }}$ Ring road (Table II). A fourth landfill, Sulaibiya, operated until 2005. The majority of the MSW is being disposed at the South $7^{\text {th }}$ Ring road landfill (Fig. 9). This is because it serves four governorates and has the largest area (Table II).

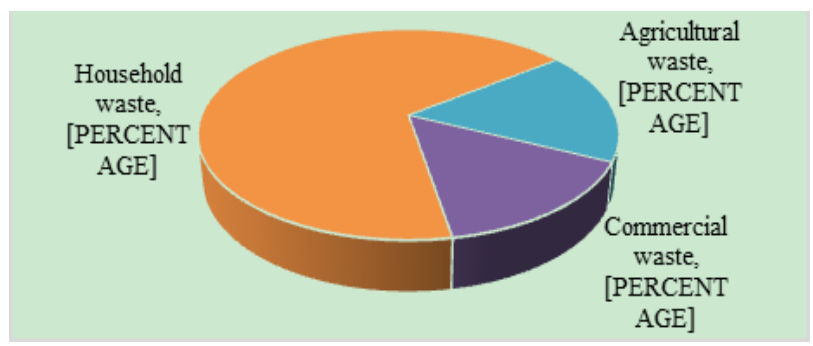

Fig. 7. The MSW in Kuwait in 2016 by sector [21].

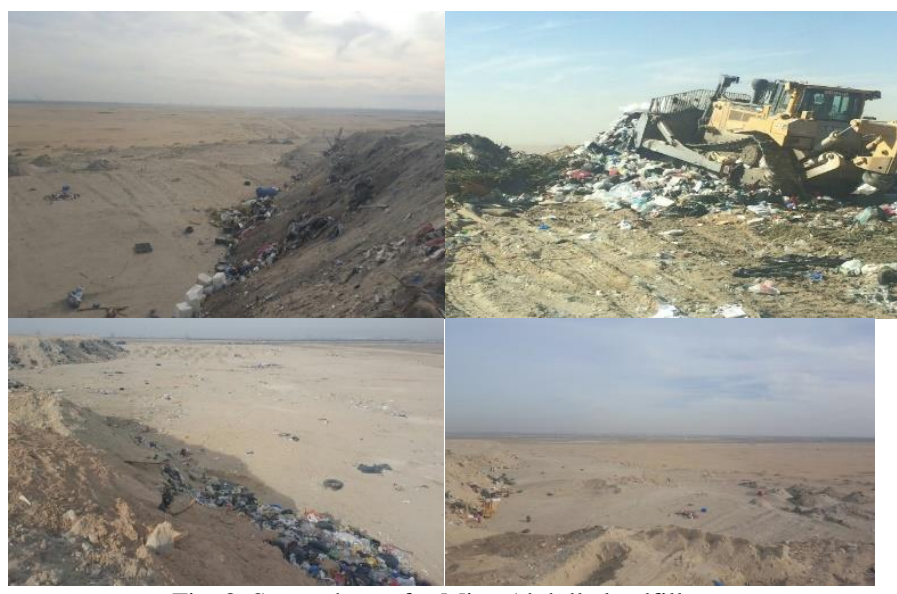

Fig. 8. Some photos for Mina Abdulla landfill.

TABLE II: DETAILS OF THE CURRENTLY OPEN MSW LANDFILLS IN KUWAIT [22]

\begin{tabular}{llll}
\hline \hline \multicolumn{1}{c}{ Landfill } & $\begin{array}{c}\text { Opening } \\
\text { year }\end{array}$ & $\begin{array}{c}\text { Area } \\
\left(\mathrm{km}^{2}\right)\end{array}$ & \multicolumn{1}{c}{ Governorates served } \\
\hline Al Jahra & 1986 & 1.72 & Al Jahra \\
\hline $\begin{array}{l}\text { Mina } \\
\text { Abdulla }\end{array}$ & 1991 & 1.14 & Al Ahmadi \\
\hline $\begin{array}{l}\text { South } 7^{\text {th }} \\
\text { Ring road }\end{array}$ & 1992 & 4.20 & $\begin{array}{l}\text { The Capital, Hawally, Farwaniya, } \\
\text { and Mubarak Al-Kabeer }\end{array}$ \\
\hline \hline
\end{tabular}

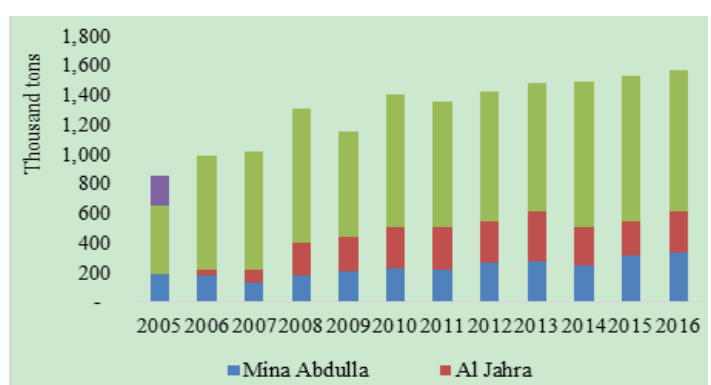

Fig. 9. Total MSW by landfill in Kuwait during 2005-2016 [21].

Results from household surveys indicate that the majority of household waste is organic waste (Fig. 7). The waste composition of the household waste in Kuwait has remained almost unchanged during the past years except for two main groups: organics and plastics. In the 2013 survey, the household waste composition results revealed that the organics, or food waste, has notably decreased from $52 \%$ in 1995 to $46 \%$ in 2013 to the favor of plastics that has increased from $13 \%$ in 1995 to $20 \%$ in 2013 (Fig. 10). This finding indicates a change in the population lifestyle for which more plastics have been used in Kuwait in the recent years. This implies that there is a need for better management of plastics where awareness campaigns can be organized to target the minimization of plastic waste.

There are no published figures on the waste diversion rate (e.g., energy recovery, composting of organic waste, recycling, or waste landfill). However, an outdated reference suggests that there were 12 recycling companies in Kuwait recycling $85 \%$ of the waste paper and $5-15 \%$ of the waste glass [22]. No recent publication confirms whether these figures are still applicable today or not.

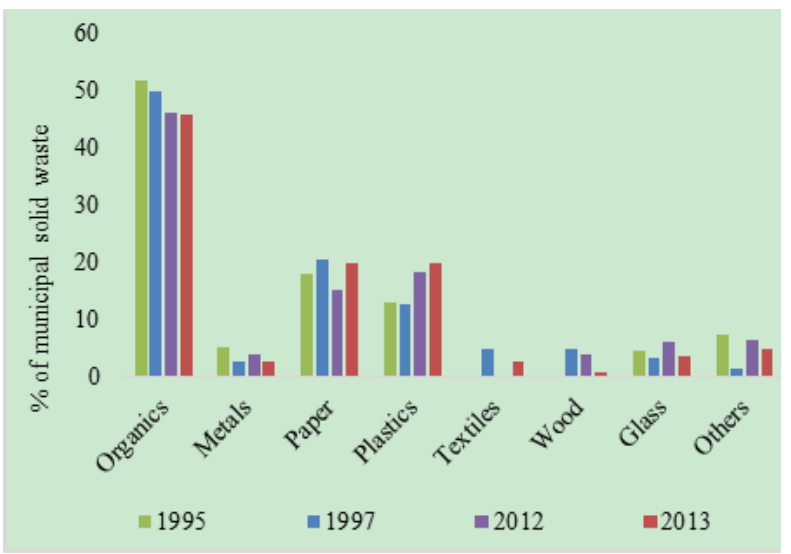

Fig. 10. The household waste composition in selected years in Kuwait [8], [23]-[25]

\section{Impacts}

There are several environmental, economic, and social impacts associated with the MSW. However, a lack of the quantification of the impacts can clearly be noticed for Kuwait. There are two main environmental impacts associated with landfills, landfill gases and leachate. The total landfill gases fluctuated over the period 1994-2003 with more than 120 million $\mathrm{m}^{3}$ in 2003 [23] (Fig. 11). The Carbon dioxide equivalent emissions $\left(\mathrm{CO}_{2} \mathrm{e}\right)$ from the waste sector made $2.4 \%$ of the country's total $\mathrm{CO}_{2} \mathrm{e}$ emissions in 1994 amounting to $784 \mathrm{Gg}$ of $\mathrm{CO}_{2} \mathrm{e}$ [26]. However, no updates for these figures or estimates for the landfill leachate are available for the recent years, neither at the concerned authorities nor in relevant literature, thus implying the need for measuring or estimating these impacts.

As for the economic impacts, there are several costs associated with the MSW including upfront cost related to the initiating of the MSWM, operating costs for managing the waste on daily basis, and back-end costs for closing the landfills or MSW facilities. These costs were not available for Kuwait, except for the operating cost for the MSW where it appears to be decreasing over time. The cost of operation decreased from 1.9 million Kuwaiti Dinars (KD) in 2005 to 1.7 million in 2009 and then significantly dropped to 0.5 million KD only in 2012 (Kuwait's Environment Public Authority, personal communication, 2017). The decrease in the operation cost of the MSW in Kuwait can be referred to the competition and contract bedding. An additional cost can be added, i.e., the opportunity cost, where the recyclable waste can be used or sold instead of being disposed. However, there are no published estimations on this matter. 
TABLE III: THE DPSIR FRAMEWORK APPLIED FOR THE MSW IN KUWAIT

\begin{tabular}{|c|c|c|c|c|}
\hline & Indicators & DP & $S$ & I \\
\hline \multirow[b]{2}{*}{ 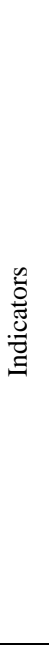 } & Available & $\begin{array}{l}\text { - Population growth } \\
(5.4 \%) \\
\text { - Economic growth }(2.6 \%) \\
\text { - Urbanization }(98 \%) \\
\text { - Households growth } \\
(7.4 \%)\end{array}$ & $\begin{array}{l}\text { - Waste generation ( } 2.3 \text { million tons) } \\
\text { - Per capita waste per year ( } 1.6 \mathrm{~kg} / \text { capita } \\
\text { in } 2016) \\
\text { - Waste characterization ( } 46 \% \text { organics, } \\
20 \% \text { plastic, } 15 \% \text { paper, } 19 \% \text { others) } \\
\text { - Total waste per sector ( } 68 \% \text { household, } \\
17 \% \text { agricultural, } 15 \% \text { commercial } \\
\text { sectors) }\end{array}$ & $\begin{array}{l}\text { - Tone of emissions generated from waste } \\
\text { management in a period of time }\left(120 \text { million } \mathrm{m}^{3} \text { in }\right. \\
\text { 2003) } \\
\text { - } \mathrm{CO}_{2} \mathrm{e} \text { emissions generated }\left(784 \mathrm{Gg} \text { of } \mathrm{CO}_{2} \mathrm{e} \text { in }\right. \\
1994)\end{array}$ \\
\hline & Not available & - & $\begin{array}{l}\text { - Waste by income group } \\
\text { - \% of households that separate waste } \\
\text { - } \% \text { of people willing to separate their } \\
\text { waste } \\
\% \text { of people that know about solid waste } \\
\text { management programs } \\
\text { - } \% \text { of waste collected to waste generated } \\
\text { - Recycling rate } \\
\text { - Amount of waste sent to landfill or } \\
\text { incinerator } \\
\text { - Waste diversion rate }\end{array}$ & $\begin{array}{l}\text { - Average operation cost per metric ton } \\
\text { - Expenditure on waste management } \\
\text { - Value of waste recycled } \\
\text { - Ton of emissions generated from waste } \\
\text { management in a period of time } \\
\text { - Energy consumption for waste management per ton } \\
\text { - \% of people not satisfied with the waste } \\
\text { management system } \\
\text { - Landfill lifespan } \\
\text { - Waste collection capacity }\end{array}$ \\
\hline \multirow{4}{*}{ 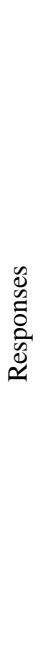 } & In place & - & $\begin{array}{l}\text { - Conduct awareness / education } \\
\text { programs }\end{array}$ & $\begin{array}{l}\text { - Environmental Protection Law No. } 42 \text { of } 2014 \text { and } \\
\text { its Executive Regulation of } 2017 \\
\text { - No new landfills are constructed or existing } \\
\text { landfills are extended without prior approval from the } \\
\text { concerned authorities. }\end{array}$ \\
\hline & $\begin{array}{l}\text { Planned by the } \\
\text { government }\end{array}$ & - & $\begin{array}{l}\text { - Prepare a national program for } \\
\text { integrated waste management by } 2021 \\
\text { - Build two waste recycling facilities }\end{array}$ & $\begin{array}{l}\text { - Build a waste-to-energy facility } \\
\text { - Proper management of landfill gases including } \\
\text { Methane for which it can be used for power } \\
\text { generation. } \\
\text { - Creating a geodatabase for waste and landfills }\end{array}$ \\
\hline & $\begin{array}{l}\text { Proposed by } \\
\text { scholars }\end{array}$ & - & - & $\begin{array}{l}\text { - Landfill gate fees (cost of landfill disposal) } \\
\text { - Indirect economic instruments to incentivize other } \\
\text { options }\end{array}$ \\
\hline & $\begin{array}{l}\text { Proposed by } \\
\text { the authors }\end{array}$ & $\begin{array}{l}\text { - Understanding the } \\
\text { differences between the } \\
\text { nationals and expats with } \\
\text { regard to waste generation. }\end{array}$ & $\begin{array}{l}\text { - Carrying out a social survey to calculate } \\
\text { the missing indicators }\end{array}$ & $\begin{array}{l}\text { - Calculating performance indicators periodically } \\
\text { - Making recycling legally mandatory } \\
\text { - Setting targets for reducing waste generation from } \\
\text { household and commercial activities. } \\
\text { - Mandating ISO } 14001 \text { for waste-relevant facilities } \\
\text { and plants }\end{array}$ \\
\hline
\end{tabular}

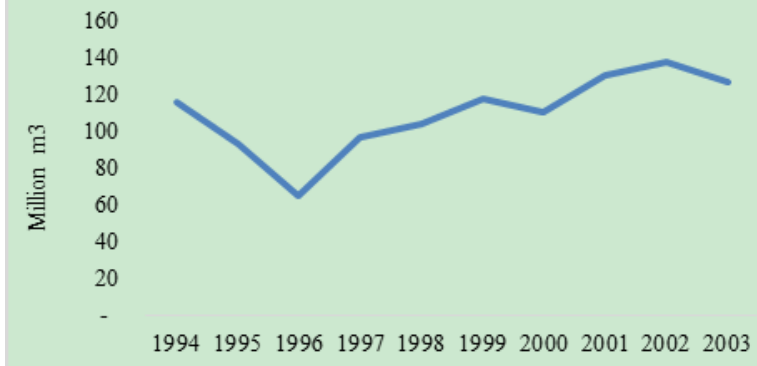

Fig. 11. Total gases from landfills in Kuwait (million m3) [23].

Similar to other impacts, there were no published assessments for the social impacts of the MSW in Kuwait except for an outdated study. (Al-Yaqout et al., 2002) investigated the public opinion towards siting MSW landfills. The study revealed that a considerable number of participants were not aware about the environmental and health effects of landfills. A social survey was conducted in (Alsulaili et al., 2014). However, only one result was reported from the survey, and it showed that $51 \%$ of participants do not recycle their waste.

\section{Responses}

Kuwait's Environmental Protection Law No. 42 was enacted in 2014 and its Executive Regulation in 2017 (Table III). This law has regulated several aspects related to the waste in general and the MSW in particular, including the selection criteria and design for landfills, the management of the MSW, and the closure of landfills. According to the law, new recycling facilities will be constructed in addition to a waste-to-energy plant. The latter project was proposed in 2000 , but the final approval has not been attained yet due to some technical and financial issues. An IMSWM strategy will be prepared as mandated by the law. To prepare the strategy, the first phase requires a household waste composition survey which has been achieved successfully in 2014. The next phases entail landfills surveys, establishment of geodatabase for waste, and preparation of the strategy by 2021. Additionally, the Kuwait Environment Public Authority has conducted several awareness campaigns to raise the public awareness towards waste sorting and recycling. Scholars have suggested a number of policies and projects to enhance the management of MSW in Kuwait including waste minimization and the at-the-source separation of recyclables (Al-Jarallah \& Aleisa, 2014) (Table III).

In response to the increase of the plastic waste, (Al-Salem, 2009) has established an integrated databank for plastic manufacturers and converters in Kuwait. On the same topic, (Al-Jarallah \& Aleisa, 2014) highlighted a new trend in the population lifestyle towards the consumption of more plastics. A comparison of the household waste composition in 1995 and 2014 revealed statistically significant variations, which needs to be considered while preparing the MSW strategy. (Alsulaili et al., 2014) had prepared an action plan 
for the MSW in Kuwait. The plan included the construction of seven recycling facilities along with suggesting collection and transportation methods and locations. The plan was economically sound with a payback period of 9.5 years and internal rate of return of $12 \%$.

A mapping of the responses against the driving forces, pressures, state, and impacts of the MSW in Kuwait reveals that the majority of the policies and projects target the impacts (Table III). The impacts of the MSW might be more visible and therefore have gained more attention; however, the state and causes are equally important and need to be addressed as well. Understanding the consumption patterns and how they differ among the various groups of population during different seasons is imperative to properly plan and manage the MSW. Setting waste-related targets and performance indicators is also of extreme importance to understand how trends change and to monitor progress towards the achievement of any relevant targets. It is also worthy to consider mandating the ISO 14001 for waste-relevant facilities and plants to ensure compliance with environmental legislations.

\section{CONCLUSION}

This paper assessed the MSWM in the State of Kuwait using the DPSIR framework. The analysis showed that the understanding of the full picture related to the MSW is still incomplete. There is a potential to adopt more waste-related practices and policies. This paper recommends the quantification of the missing indicators along with the establishment of a national waste database. This is to monitor and assess the effectiveness of different waste management policies. The method applied in this paper can be implemented in other GCC countries. This is to portray and assess the current state related to the MSW and prepare a unified performance indicators' list for the GCC countries which would be in line with the IMSWM GCC guidelines. The GCC countries can also share their experiences and best practices through the initiation of a waste-related GCC network. Acting collaboratively as a region offers the opportunity for policy transfer and learning and fosters the adoption of the IMSWM.

\section{REFERENCES}

[1] US-EPA. (2009). Waste definitions. [Online]. Available: https://www.epa.sa.gov.au/files/4771336_guide_waste_definitions.pd f.

[2] Eurostat. (2018). Municipal waste. [Online]. Available: https://ec.europa.eu/eurostat/web/waste/transboundary-waste-shipmen ts/key-waste-streams/municipal-waste

[3] GCC-SG. (2018). A guide to solid waste management in the GCC countries. [Online]. Available: http://globalsummitryproject.com.s197331.gridserver.com/archive/cca sg/sites.gcc-sg.org/DLibrary/download90f1.pdf?B=613

[4] P. A. Koushki and A. L. Al-Khaleefi, "An analysis of household solid waste in Kuwait: Magnitude, type, and forecasting models," J Air Waste Manag Assoc, 1998, vol. 48, no. 3, pp. 256-263.

[5] A. Al-Yaqout, P. Koushki, and M. Hamoda, "Public opinion and siting solid waste landfills in Kuwait," Resources, Conservation and Recycling, 2002, vol. 35, pp. 215-227.
[6] S. M. Al-Salem, "Establishing an integrated databank for plastic manufacturers and converters in Kuwait," Waste Manag, 2009, vol. 29, no. 1 , pp. 479-84.

[7] A. Alsulaili et al., "An integrated solid waste management system in Kuwait," International Proceedings of Chemical, Biological and Environmental Engineering, 2014, vol. 69, pp. 54-59.

[8] R. Al-Jarallah and E. Aleisa, "A baseline study characterizing the municipal solid waste in the State of Kuwait," Waste Manag, 2014, vol. 34, no. 5, pp. 952-60.

[9] E. Aleisa, R. Al-Jarallah, and D. Shehada, "The effect of geological and meteorological conditions on municipal waste management systems: A life cycle assessment approach," 2018.

[10] E. Aleisa and R. Al-Jarallah, "A triple bottom line evaluation of solid waste management strategies: A case study for an arid Gulf State, Kuwait," The International Journal of Life Cycle Assessment, 2018, vol. 23, no. 7, pp. 1460-1475.

[11] A. Allesch and P. H. Brunner, "Assessment methods for solid waste management: A literature review," Waste Management \& Research, 2014, vol. 32, no. 6, pp. 461-473.

[12] EEA. (2018). The DPSIR framework. [Online]. Available: https://www.eea.europa.eu/publications/92-9167-059-6-sum/page002. html

[13] A. Chavez, C. Vega, and S. Benitez, "Measuring progress of waste management programs," International Journal of Environmental Science and Development, 2011, vol. 2, no. 5, pp. 372-376.

[14] K. L. Greene and D. J. Tonjes, "Quantitative assessments of municipal waste management systems: using different indicators to compare and rank programs in New York State," Waste Manag, 2014, vol. 34, no. 4, pp. 825-36.

[15] V. Sanjeevi and P. Shahabudeen, "Development of performance indicators for municipal solid waste management (PIMS): A review," Waste Manag Res, 2015, vol. 33, no. 12, pp. 1052-65.

[16] D. Căilean and C. Teodosiu, "An assessment of the Romanian solid waste management system based on sustainable development indicators," Sustainable Production and Consumption, 2016, vol. 8, pp. 45-56.

[17] C. Teixeira. (2018). Municipal solid waste performance indicators. [Online]. Available: https://www.iswa.org/uploads/tx_iswaknowledgebase/1-265.pdf

[18] L. Arendse and L. Godfrey, Waste Management Indicators for National State of Environment Reporting, 2018.

[19] T. W. Bank. (2018). Kuwait. [Online]. Available: https://data.worldbank.org/country/Kuwait

[20] A. Gaber, M. Riad, and R. El-Sherbiny, Waste Management in Green Economy, 2011, AFED: Beirut.

[21] K.-C. S. Bureau, Annual Statistical Abstract, 2018.

[22] S. Muqeem, Assessment of Municipal Solid Waste Management in Kuwait, 2006, Arabian Gulf University: Bahrain

[23] M. Al-Faraj, "Landfill sites in the State of Kuwait and their impact on the residential areas - An analytical geographical study," 2005.

[24] F. Al-Hajri, "The effect of transfer of the technology of recycling of solid waste from the environmental and economical prospective," 2004, Arabian Gulf University: Bahrain.

[25] FICHTNER, Waste Composition and Characterization Study, 2014.

[26] Kuwait-EPA, Kuwait's Initial National Communications under the United Nations Framework Convention on Climate Change, 2012, Kuwait.

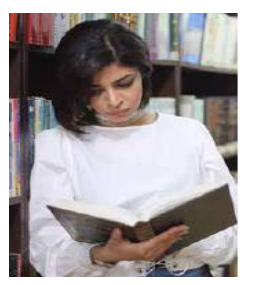

Areej Al Lahou is a master student at the Department of Natural Resources and Environment, Kingdom of Bahrain.

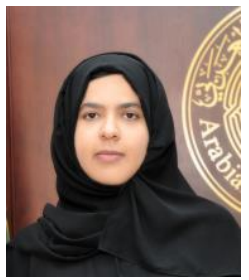

Maha Alsabbagh is at the Department of Natural Resources and Environment, Kingdom of Bahrain. 